\title{
Pengembangan Media Pembelajaran Berbasis Android untuk Mata Pelajaran Fisika Materi Pokok Energi di Kelas X IPA 1 SMA Negeri 2 Muara Badak Tahun Ajaran 2019/2020
}

\author{
Galih Yudha Saputra, Arif Harjanto, Yunita Andrian Ningsih \\ Pendidikan Komputer, Fakultas Keguruan Ilmu Pendidikan, Universitas Mulawarman Samarinda \\ J1. Muara Pahu Kampus Gn. Kelua, Samarinda, 75123, Indonesia \\ galih.yudha@fkip.unmul.ac.id
}

\begin{abstract}
Abstrak
Mata pelajaran fisika merupakan mata pelajaran yang dirasa siswa sulit untuk dipahami. Dengan mengintegrasikan smartphone dengan pembelajaran khususnya pada mata pelajaran fisika, diharapkan dapat membantu pendidik agar siswa yang tidak begitu suka dengan mata pelajaran fisika bisa menyukai mata pelajaran tersebut. Pembelajaran melalui media smartphone lebih praktis dilakukan dimana saja dan kapan saja sehingga dapat membuat siswa lebih mudah dalam belajar. Metode penelitian yang digunakan dalam pengembangan media pembelajaran berbasis android untuk mata pelajaran fisika materi pokok energi adalah metode 4D. Uji kelayakan dapat dilihat pada perolehan hasil angket yang dilakukan kepada ahli materi dan ahli media. Berdasarkan keseluruhan penilaian dari ahli materi dan ahli media terhadap pengembangan media pembelajaran berbasis android diperoleh rata-rata sebesar 96,5 dengan kategori sangat layak. Sehingga pengembangan media pembelajaran berbasis android untuk mata pelajaran fisika materi pokok energi sangat layak digunakan pada siswa kelas X IPA 1 SMA Negeri 2 Muara Badak Tahun Ajaran 2019/2020.
\end{abstract}

Kata kunci: media pembelajaran berbasis Android, Mata Pelajaran Fisika, materi pokok energi, Adobe Flash Professional CS6

\section{Pendahuluan}

Media pembelajaran berbasis android dapat digunakan dalam kegiatan pembelajaran sebab cukup efektif meningkatkan hasil belajar peserta didik, serta dapat meningkatkan efektifitas dan efesiensi pembelajaran (Yudhi Munadi, 2013). Siswa dapat belajar dimanapun dan kapanpun sambil melakukan aktifitas media sosial ataupun hiburan melalui android. Hasil penelitian oleh Alfina (2013) menunjukkan bahwa pengembangan aplikasi android dapat meningkatkan minat belajar siswa, karena pada smartphone android terdapat kemampuan zoom in dan zoom out yang lebih mudah digunakan.

Berdasarkan hasil wawancara dengan guru fisika kelas X IPA 1 di SMA Negeri 2 Muara Badak pada tanggal 16 Januari 2020, penyampaian materi fisika baru menggunakan media presentasi powerpoint. Adapun laboratorium komputer di SMA Negeri 2 Muara badak belum bisa digunakan, dikarenakan masih dalam tahap pengoperasian. Untuk penggunaan media pembelajaran berbasis android belum pernah diterapkan pada mata pelajaran fisika. Metode pembelajaran yang diterapkan masih menggunakan metode konvensional. Pada saat proses pembelajaran $75 \%$ persen siswa aktif di dalam kelas, sedangkan 25\% siswa pasif atau hanya mengikuti temannya yang lain.

Berdasarkan hasil observasi dengan siswa kelas X IPA 1 di SMA Negeri 2 Muara Badak, hanya beberapa siswa yang memiliki laptop sedangkan smartphone semua siswa sudah memilikinya. Sehingga penerapan media pembelajaran berbasis android dapat memanfaatkan smartphone siswa untuk proses pembelajaran. Peneliti melakukan penelitian pada mata pelajaran fisika, karena pada mata pelajaran ini hampir semua materinya menggunakan rumus. Sehingga tidak jarang semua siswa langsung paham dengan materi yang diajarkan. Penerapan media pembelajaran berbasis android dapat digunakan sebagai pembelajaran jarak jauh, karena siswa dapat menggunakan media pembelajaran tersebut dimana dan kapan saja bahkan bisa digunakan berkali-kali. Penggunaan media pembelajaran berbasis android di 
SMA Negeri 2 Muara diharapkan dapat membantu guru dalam menyampaikan materi pembelajaran agar siswa bisa tetap serius walau dalam keadaan santai. Peneliti mencoba menggabungkan kesukaan siswa yaitu menggunakan smartphone dengan pembelajaran khususnya pada mata pelajaran fisika, sehingga diharapkan dapat membantu guru agar siswa yang tidak begitu suka dengan mata pelajaran fisika bisa menyukai mata pelajaran tersebut.

Berdasarkan uraian diatas, penulis selaku peneliti termotivasi untuk mengembangkan media pembelajaran berbasis android dalam bentuk aplikasi media pembelajaran untuk mata pelajaran fisika materi pokok energi di kelas X IPA 1 SMA Negeri 2 Muara Badak. Pembelajaran melalui media smartphone akan lebih praktis dilakukan dimana saja dan kapan saja sehingga dapat membuat siswa lebih mudah dalam belajar.

Tujuan penelitian ini adalah:

1) Mengetahui proses pengembangan media pembelajaran berbasis android pada mata pelajaran fisika materi pokok energi di kelas X IPA 1 SMA Negeri 2 Muara Badak.

2) Mengetahui kelayakan dari menggunakan media pembelajaran berbasis android pada mata pelajaran fisika materi pokok energi di kelas X IPA 1 SMA Negeri 2 Muara Badak.

\section{Metode Penelitian}

Pengembangan media pembelajaran berbasis android ini menggunakan metode penelitian dan pengembangan (research and development). Menurut Sugiyono (2011: 297) penelitian dan pengembangan merupakan metode penelitian dengan tujuan untuk menghasilkan produk tertentu, dan menguji keefektifan produk tersebut. Pendapat lain diungkapkan oleh Endang Mulyatiningsih (2011: 161) yaitu "penelitian dan pengembangan bertujuan untuk menghasilkan produk baru melalui proses pengembangan". Secara umum, penelitian dan pengembangan merupakan penelitian yang bertujuan untuk menghasilkan produk baru dan menguji keefektifan produk tersebut.

Model pengembangan yang digunakan dalam penelitian ini menggunakan model pengembangan 4D. Menurut Thiagarajan (dalam Sugiyono, 2015: 37) mengemukakan bahwa langkah-langkah penelitian dan pengembangan disingkat dengan 4D yang merupakan perpanjangan dari Define, Design, Development, and Dissemination. Model penelitian 4D lebih tepat digunakan untuk pengembangan media pembelajaran berbasis web maupun software sehingga dapat dikembangkan secara sistematis, serta mudah dipahami dan dipelajari dalam pengembangan sebuah media pembelajaran.

Data yang akan dikumpulkan dalam penelitian ini terdiri dari dua data, yaitu data kualitatif dan kuantitatif. Sedangkan Instrument pengumpulan data yang digunakan adalah angket atau kuisioner. Menurut Sugiyono (2011: 142) angket atau kuisioner merupakan teknik pengumpulan data yang dilakukan dengan cara memberi seperangkat pertanyaan atau pernyataan tertulis kepasa responden untuk dijawabnya. Angket digunakan untuk mengukur kualitas media yang memperoleh data dari ahli media, ahli materi, dan siswa sebagai bahan mengevaluasi media pembelajaran yang dikembangkan.

Data yang telah terkumpul akan dianalisis untuk mengetahui penilaian dan pendapat dari produk yang dihasilkan.

1) Data Proses Pengembangan Produk

Data proses pengembangan produk merupakan data deskriptif. Data proses pengembangan produk diperoleh dari ahli materi, ahli media, dan siswa berupa koreksi dan masukan. Koreksi dan masukan tersebut digunakan sebagai acuan revisi produk.

2) Data Penilaian Kelayakan Produk

Data untuk analisis kelayakan didapat dari angket validasi oleh dosen ahli media pembelajaran, dosen ahli materi dan angket penilaian oleh siswa. Data ini berupa skala penilaian yang terdiri dari lima skala penilaian, yaitu sangat layak, layak, cukup layak, kurang layak dan tidak layak. 
Analisis data ini dilakukan dalam beberapa tahapan beikut ini:

a. Tabulasi data yang diperoleh untuk setiap aspek penilaian dan butir penilaian media dari setiap penilai. Setiap butir penilaian media yang menyatakan:

Tabel 1. Skor penilaian

\begin{tabular}{cc}
\hline Kategori & Skor \\
\hline Sangat Setuju & 5 \\
Setuju & 4 \\
Cukup Setuju & 3 \\
Tidak Setuju & 2 \\
Sangat Tidak Setuju & 1 \\
\hline Sumber: Sugiyono (2015: 165$)$
\end{tabular}

b. Menghitung skor total rerata dari setiap aspek penilaian dengan menggunakan rumus

$$
\text { Mean } \bar{X}=\frac{\sum x}{N}
$$

Keterangan:

$\bar{X}=$ Skor rata-rata

$\sum \mathrm{x}=$ Jumlah skor

$\mathrm{N}=$ (Jumlah Responden)

c. Mengonversi skor yang diperoleh menjadi nilai kualitatif seperti yang tersaji pada tabel 2 sebagai berikut:

Tabel 2. Rumus Konversi Jumlah Rerata Skor

\begin{tabular}{cc}
\hline Interval Nilai & Kategori \\
\hline$\overline{\mathbf{X}}>\mathrm{Xi}+1,80 \mathrm{SBi}$ & Sangat Layak \\
$\mathrm{Xi}+0,60 \mathrm{SBi}<\overline{\mathbf{X}} \leq \mathrm{Xi}+1,80 \mathrm{SBi}$ & Layak \\
$\mathrm{Xi}-0,60 \mathrm{SBi}<\overline{\mathbf{X}} \leq \mathrm{Xi}+1,60 \mathrm{SBi}$ & Cukup Layak \\
$\mathrm{Xi}-1,80 \mathrm{SBi}<\overline{\mathbf{X}} \leq \mathrm{Xi}+1,60 \mathrm{SBi}$ & Tidak Layak \\
$\overline{\mathbf{X}} \leq \mathrm{Xi}-1,80 \mathrm{SBi}$ & Sangat Tidak Layak \\
\hline Sumber: Suartama dalam Mubarok (2015:58)
\end{tabular}

Keterangan:

Skor Maksimal $=5$

Skor Minimal $=1$

Skor Maksimal Ideal $=$ jumlah indikator $\times$ skor tertinggi

Skor Minimal Ideal $=$ jumlah indikator $\times$ skor terendah

$\mathrm{Xi}=$ Rerata $=\frac{1}{2}($ Skor maks ideal + Skor min ideal $)$

$\mathrm{SBi}=$ Simpangan Baku Ideal $=\frac{1}{6}($ Skor maks ideal - Skor min ideal $)$

Berdasarkan pedoman tabel 2. Konversi nilai skala lima data tersebut, maka setelah mendapatkan data-data kuantitatif untuk mengubah ke dalam data kualitatif pada pengembangan ini diterapkan rumus konversi sebagai berikut:

Skor maksimal ideal $=5$

Skor minimal ideal $=1$

$\mathrm{Xi}=\frac{1}{2}(5+1)=3$

$\mathrm{SBi}=\frac{1}{6}(5-1)=0,6$ 


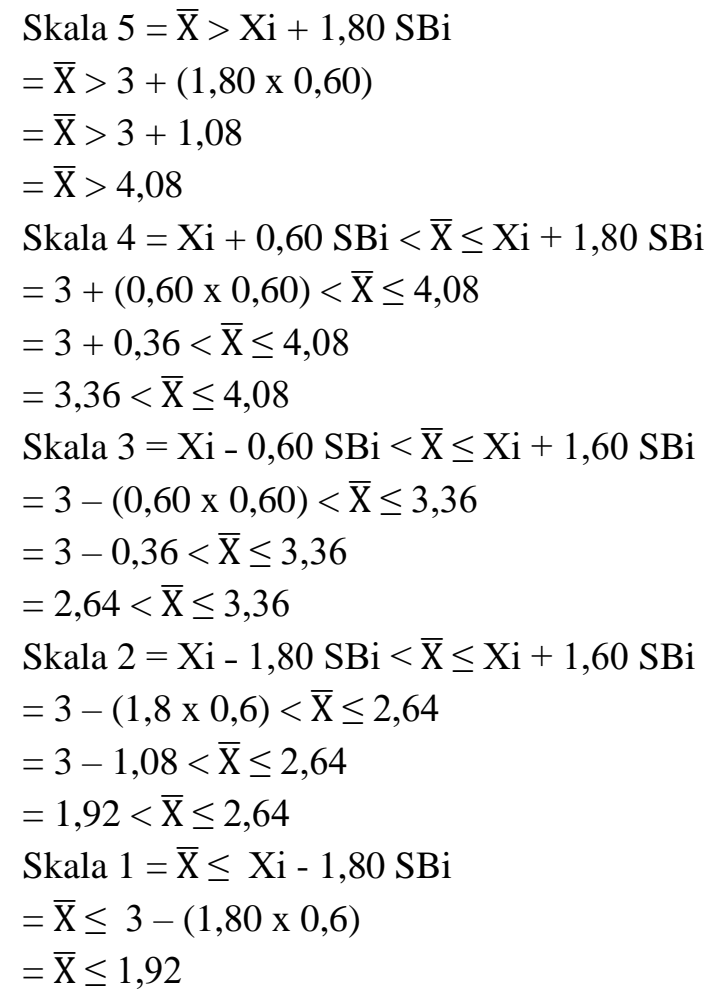

Atas dasar perhitungan rumus konversi tersebut, maka konversi data kuantitatif ke dalam data kualitatif skala lima dapat disederhanakan ke dalam bentuk pedoman skala likert, sebagaimana tertulis pada tabel 2. Pedoman skala likert sebagai berikut:

Tabel 3. Pedoman skala likert

\begin{tabular}{ccc}
\hline Nilai & Interval Skor & Kriteria \\
\hline 5 & $\overline{\mathrm{X}}>4,08$ & Sangat Layak \\
4 & $3,36<\overline{\mathrm{X}} \leq 4,08$ & Layak \\
3 & $2,64<\overline{\mathrm{X}} \leq 3,36$ & Cukup Layak \\
2 & $1,92<\overline{\mathrm{X}} \leq 2,64$ & Tidak Layak \\
1 & $\overline{\mathrm{X}} \leq 1,92$ & Sangat Tidak Layak \\
\hline \multicolumn{3}{c}{ Sumber: Sugiyono dalam Mubarok (2015:60). }
\end{tabular}

Setelah data penelitian dikumpulkan dengan menggunakan lembar validasi ahli media, dan ahli materi, serta analisa data menggunakan skala likert.

\section{Hasil dan Pembahasan}

a. Tahap Pendefinisian (Define)

1) Analisis awal-akhir (Front-end analysis)

Masalah dasar yang terjadi pada pembelajaran fisika adalah masih ada beberapa siswa yang kurang aktif dalam proses pembelajaran yang menggunakan metode konvensional dikarenakan banyaknya siswa yang harus diajar oleh seorang pendidik. Dengan hal ini, peneliti memutuskan untuk mengembangkan media pembelajaran yang dapat membantu siswa dalam belajar mandiri.

\section{2) Analisis konsep (Concept analysis)}

Kegiatan yang dilakukan dalam tahap ini adalah analisis terhadap silabus mata pelajaran fisika, sehingga dihasilkan garis besar materi yang akan disajikan dalam media pembelajaran yang akan 
dikembangkan. Berdasarkan pada analisis ini materi yang akan diterapkan adalah materi Energi kelas X dengan beberapa indikator pembelajaran yang akan dicapai yaitu, siswa mampu menuliskan pengertian dari energi, siswa mampu menuliskan jenis-jenis dari energi, dan siswa mampu menuliskan penerpan energi dalam kehidupan sehari-hari.

3) Analisis tugas (Task analysis)

Analisis ini dimastikan ulasan yang menyeluruh tentang tugas dalam materi pembelajaran. Rincian analisis tugas untuk materi energi pada kompetensi dasar yang diamati merujuk pada indikator pembelajaran yang ingin dicapai sesuai dengan analisis konsep.

4) Analisis tujuan pembelajaran (Specifying instructional objectives)

Specifying instructional objectives atau perumusan tujuan pembelajaran merupakan perubahan perilaku yang diharapkan setelah belajar. Sehingga pada tahap analisis ini siswa yang masih pasif diharapkan bisa menjadi aktif pada proses pembelajaran berlangsung.

5) Analisis kebutuhan sistem (System requirements analysis)

a) Analisis kebutuhan input. Input (masukan) dari pembuatan media pembelajaran fisika materi pokok energi adalah sebagai berikut:

$\checkmark$ Data-data informasi mengenai materi energi.

$\checkmark$ Gambar-gambar atau foto yang dibutuhkan.

$\checkmark$ Animasi tambahan yang dibutuhkan.

b) Analisi kebutuhan output. Output (keluaran) dari pembuatan media pembelajaran fisika materi pokok energi adalah berupa tampilan teks, gambar, dan animasi yang telah diolah. Dengan adanya tampilan gambar, animasi, dan juga teks diharapkan siswa sebagai pengguna dapat menikmati dan memahami pembelajaran yang disajikan dalam media pembelajaran fisika materi pokok energi.

c) Analisis kebutuhan perangkat keras (hardware). Spesifikasi komponen perangkat keras yang digunakan untuk pembuatan media pembelajaran fisika materi pokok energi adalah:

$\checkmark \quad$ PC atau laptop dengan prosesor Core i5.

$\checkmark$ RAM 4 GB

$\checkmark \quad$ Keyboard dan mouse sebagai piranti input.

$\checkmark \quad$ Monitor sebagai piranti output.

d) Analisis kebutuhan perangkat lunak (software). Perangkat lunak yang dibutuhkan pada pembangunan media pembelajaran adalah sebagai berikut:

$\checkmark$ Sistem operasi yang digunakan untuk membuat media pembelajaran antara lain Windows 10.

$\checkmark$ Adobe Flash Professional CS6 digunakan untuk pembuatan media pembelajaran.

$\checkmark$ Corel Draw X7 digunakan untuk mengedit gambar dan background sebagai tambahan pembuatan media pembelajaran.

\section{b. Tahap Perancangan}

1) Penyusunan tes (criterion-test construction)

Penyusunan tes instrument merupakan kegiatan yang dilakukan peneliti untuk menyusun konsep tes instrument yang akan digunakan dengan mengacu pada tujuan pembelajaran sebagai tolak ukur kemampuan siswa selama dan setelah kegiatan pembelajaran.

2) Desain awal (initial design)

Desain awal media pembelajaran berupa pembuatan actifity diagram, pemuatan flowchart, pembuatan desain media secara keseluruhan (storyboard), pembuatan background, gambar dan tombol yang akan disertakan dalam aplikasi. 


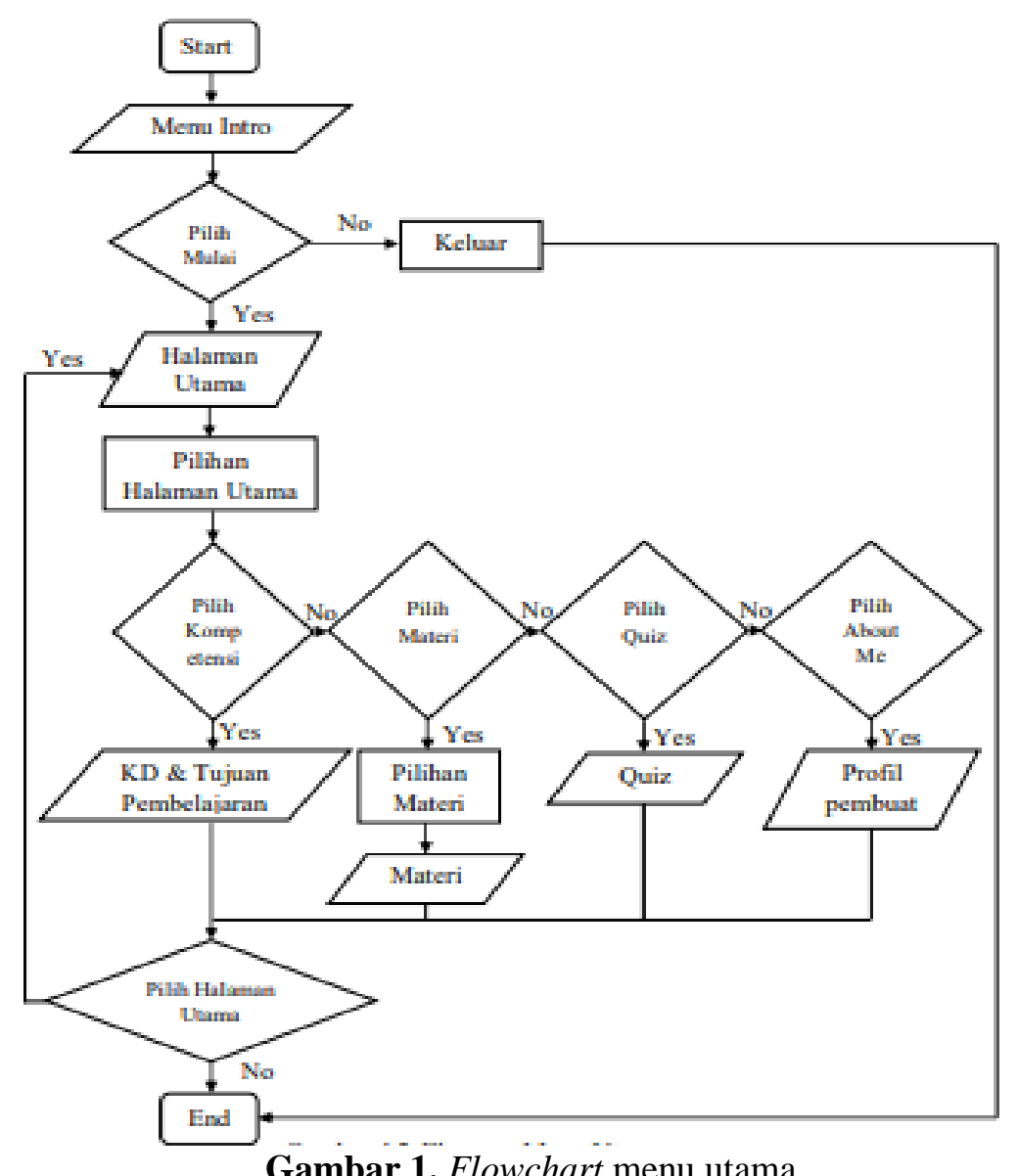

\section{c. Tahap Pengembangan (Development)}

1) Pembuatan media pembelajaran

Pada tahap ini peneliti mulai membuat media pembelajaran dengan menggunakan aplikasi Adobe Flash Professional CS6. Media pembelajaran dimuat dalam format file Android Package (.apk) dan siap untuk diinstal pada smartphone dengan sistem operasi Android sesuai dengan spesifikasi yang telah ditentukan.

a) Halaman Loading

Pada halaman loading merupakan halaman berisi hak cipta dari pembuat. Pada halaman loading akan menuju ke halaman menu awal.
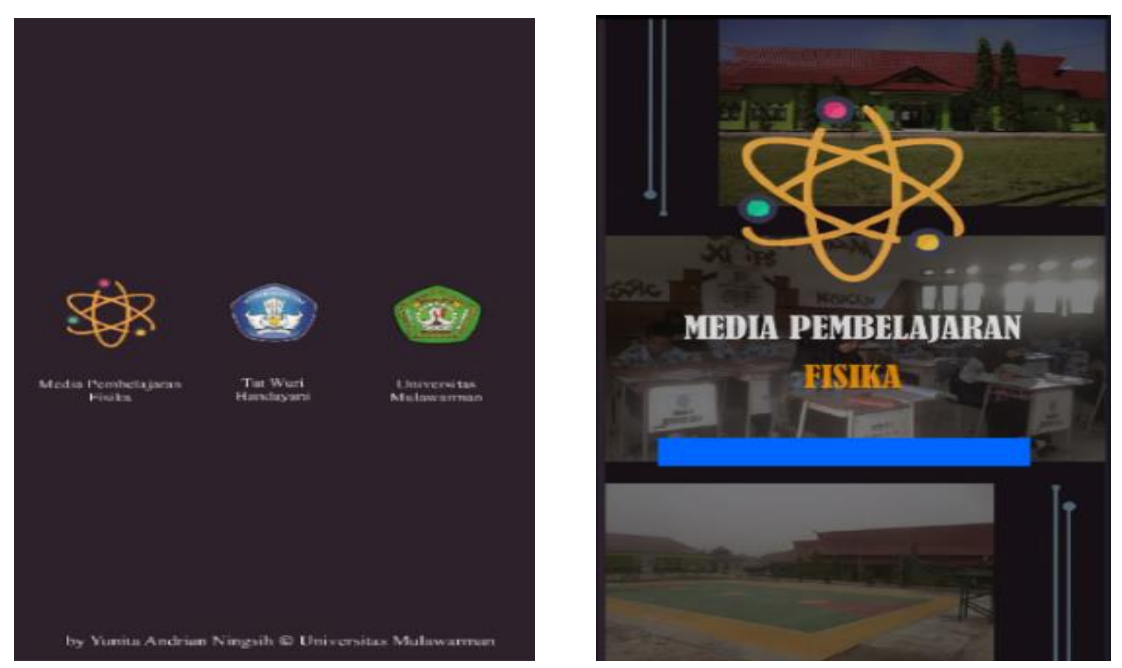

Gambar 2. Halaman loading 
b) Halaman Menu Awal

Pada halaman menu awal terdapat tombol mulai untuk menuju ke halaman menu utama dan tombol keluar untuk keluar dari aplikasi.

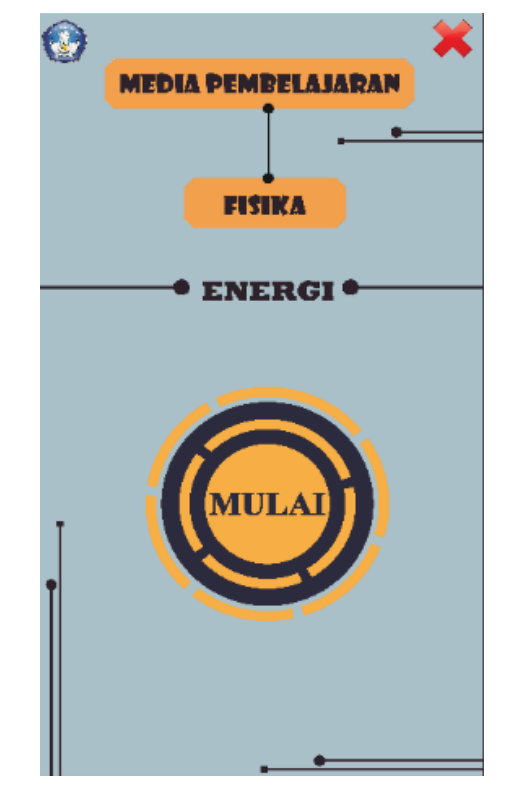

Gambar 3. Halaman menu awal

c) Halaman Sebelum Keluar Aplikasi

Pada saat tombol X (keluar) dipilih akan tampil halaman sebelum keluar aplikasi. Pada halaman sebelum keluar aplikasi terdapat tombol ya dan tidak. Tombol ya dipilih akan keluar aplikasi sedangkan tombol tidak dipilih akan kembali ke aplikasi atau batal keluar aplikasi.

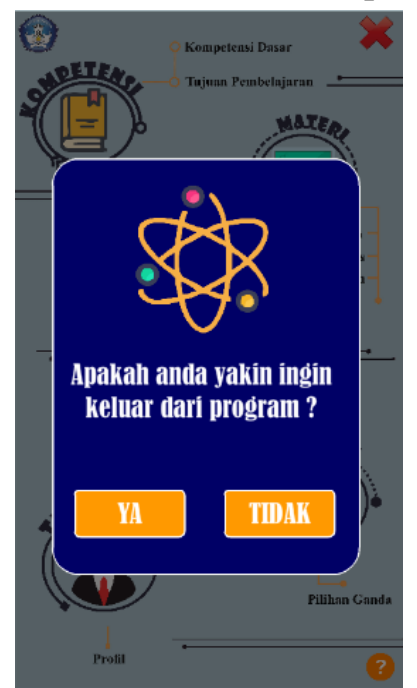

Gambar 4. Halaman sebelum keluar aplikasi

\section{d) Halaman Menu Utama}

Pada saat tombol mulai dipilih akan tampil halaman menu utama. Pada halaman menu utama terdapat 6 tombol yaitu, tombol keluar, tombol kompetensi, tombol materi, tombol quiz, tombol about me, dan tombol petunjuk menu. Tombol kompetensi dipilih akan menuju ke halaman kompetensi. Tombol materi dipilih akan menuju ke halaman materi. Tombol quiz dipilih akan menuju ke halaman quiz, tombol about me untuk menuju ke halaman about me, dan tombol petunjuk menu untuk menuju ke halaman petunjuk menu utama. 


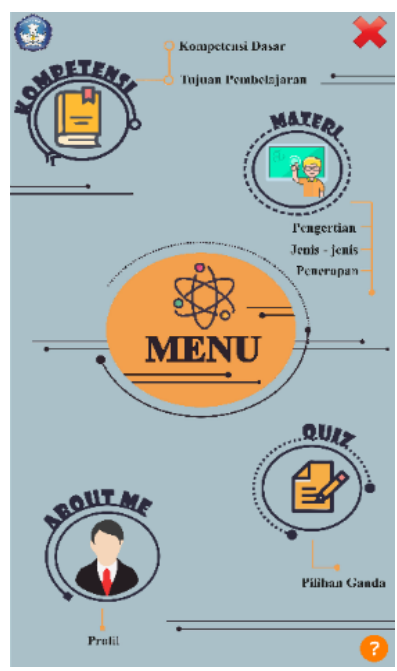

Gambar 5. Halaman menu utama

e) Halaman Petunjuk Menu Utama

Pada saat tombol petunjuk dipilih akan tampil halaman petunjuk menu utama. Pada halaman petunjuk menu utama terdapat penjelasan navigasi atau tombol dari halaman menu utama dan terdapat tombol kembali untuk kembali ke halaman menu utama.

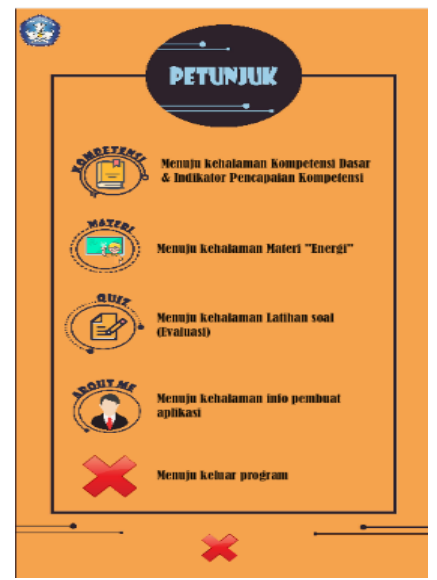

Gambar 6. Halaman petunjuk menu utama

f) Halaman Kompetensi

Pada saat tombol kompetensi dipilih akan tampil halaman kompentensi. Pada halaman terdapat kompetensi dasar, tujuan pembelajaran, tombol keluar, dan tombol home. Tombol home dipilih akan menuju ke halaman ke menu utama.

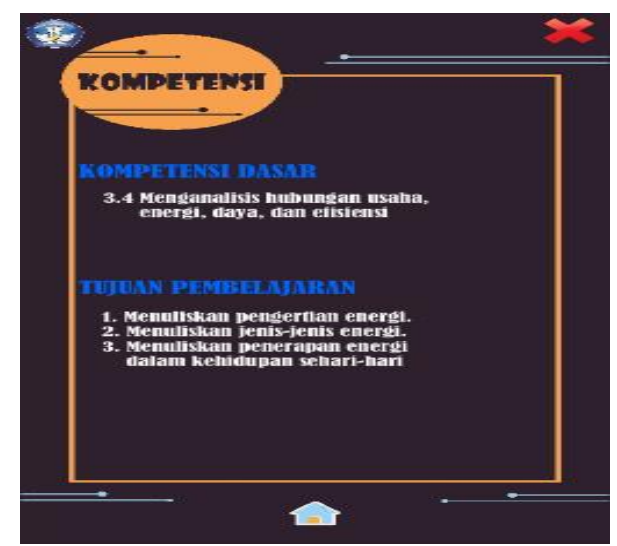

Gambar 7. Halaman kompetensi 


\section{g) Halaman Menu Materi}

Pada saat tombol materi dipilih akan tampil halaman materi. Pada halaman menu materi terdapat beberapa 6 tombol yaitu, tombol keluar, tombol pengertian, tombol jenis-jenis, tombol penerapan, tombol home, dan tombol petunjuk. Tombol pengertian dipilih akan menuju ke halaman pengertian. Tombol jenis-jenis dipilih akan menuju ke halaman jenis-jenis. Tombol penerapan dipilih akan menuju ke halaman penerapan.

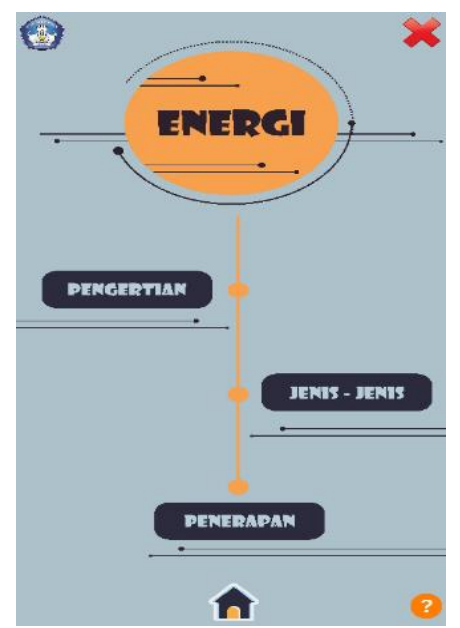

Gambar 8. Halaman menu materi

\section{h) Halaman Materi}

Pada halaman materi berisi tentang pengertian, jenis-jenis, dan penerapan. Pada halaman pengertian berisi tentang materi pengertian. Pada halaman jenis-jenis berisi tentang materi pengertian, rumus, dan contoh soal dari masing-masing jenis-jenis. Pada halaman penerapan berisi tentang materi penerapan berupa animasi. Pada setiap halaman terdapat tombol keluar, tombol home, tombol kembali, dan tombol selanjutnya. Tombol kembali dipilih akan menuju ke halaman sebelumnya sedangkan tombol selanjutnya dipilih akan menuju ke halaman selanjutnya.

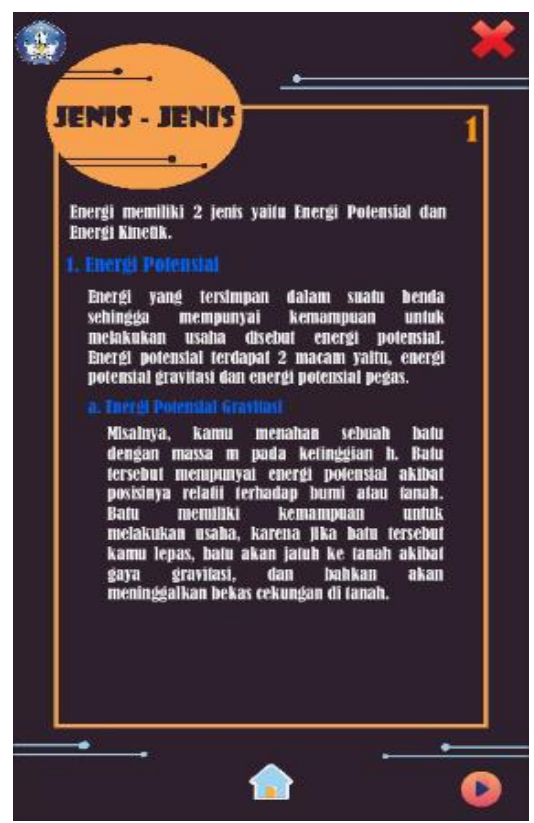

Gambar 9. Halaman Materi 
i) Halaman Petunjuk Menu Materi

Pada saat tombol petunjuk dipilih akan tampil halaman petunjuk menu materi. Pada halaman petunjuk menu materi terdapat penjelasan navigasi atau tombol dari halaman menu materi dan terdapat tombol kembali untuk kembali ke halaman menu materi.

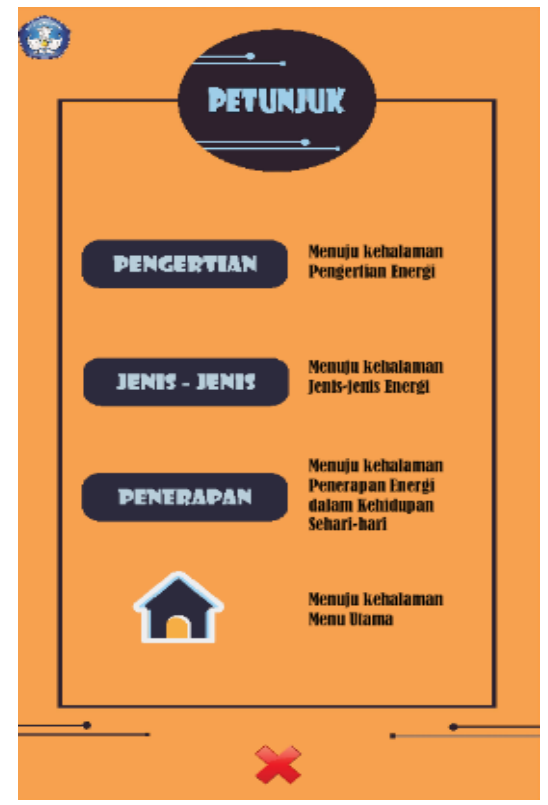

Gambar 10. Halaman petunjuk menu materi

j) Halaman Identitas

Pada saat tombol quiz dipilih akan tampil halaman identitas untuk mengisi identitas siswa sebelum mulai mengerjakan quiz. Pada halaman identitas berisi nama, kelas, dan nomor absen, sedangkan untuk tombol terdapat tombol keluar, tombol mulai, dan tombol home. Tombol mulai dipilih untuk memulai mengerjakan quiz dan menuju ke halaman soal quiz.
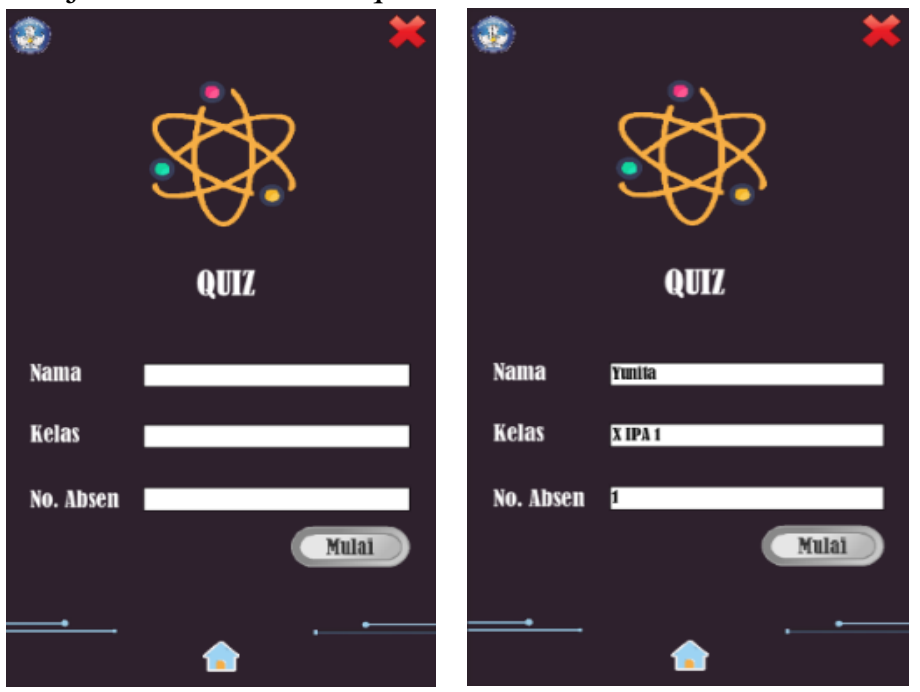

Gambar 11. Halaman identitas 


\section{k) Halaman Soal Quiz}

Pada halaman soal quiz terdapat soal dan pilihan jawaban, dimana pilihan jawaban terdiri dari pilihan A, B, C, D, dan E. Pada halaman soal juga berisi keterangan jawaban salah atau benar, jumlah point dan tombol untuk menuju ke halaman selanjutnya.
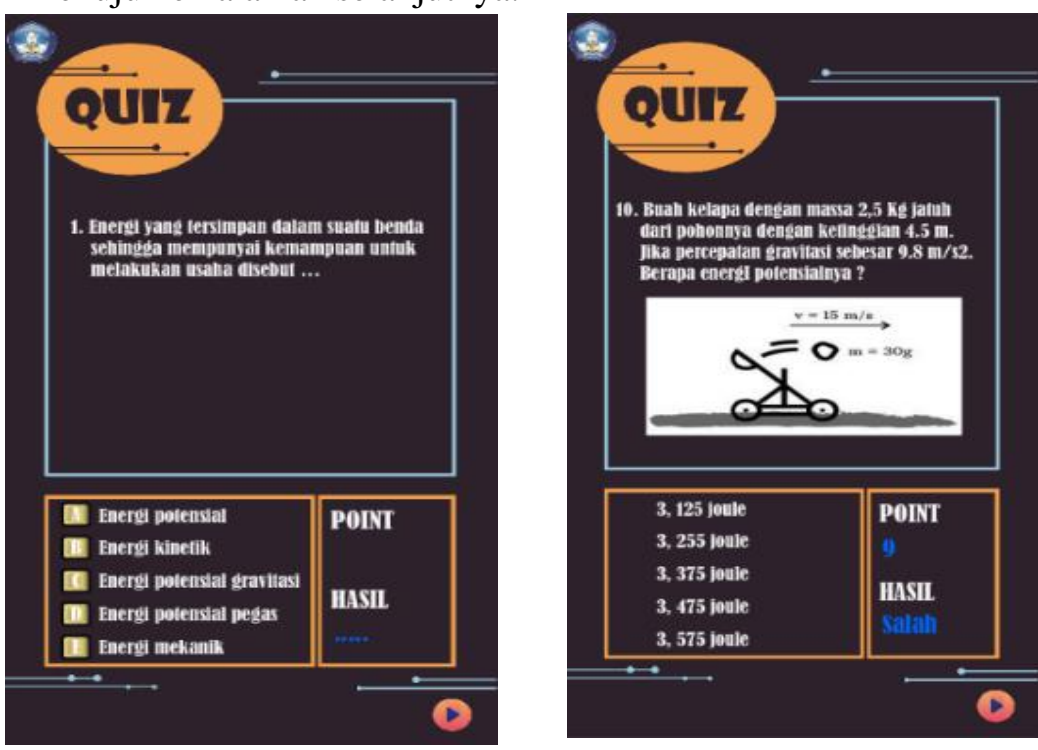

Gambar 12. Halaman soal quiz

1) Halaman Skor Penilaian

Pada halaman skor penilaian terdapat identitas siswa, skor siswa, jumlah soal yang benar, jumlah soal yang salah, dan keterangan. Pada halaman skor penilaian juga terdapat tombol keluar dan tombol ulang. Tombol ulang dipilih akan menuju ke halaman identitas.

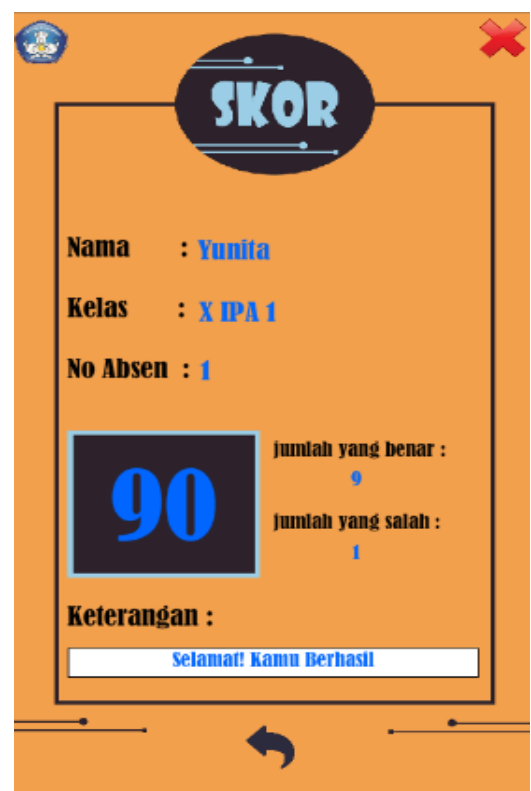

Gambar 13. Halaman skor penilaian 


\section{m) Halaman About Me}

Pada saat tombol about me dipilih akan tampil halaman about me. Pada halaman about me berisi informasi aplikasi seperti, informasi aplikasi yang digunakan dan informasi tentang pembuat aplikasi. Pada halaman about me terdapat tombol keluar dan tombol home.

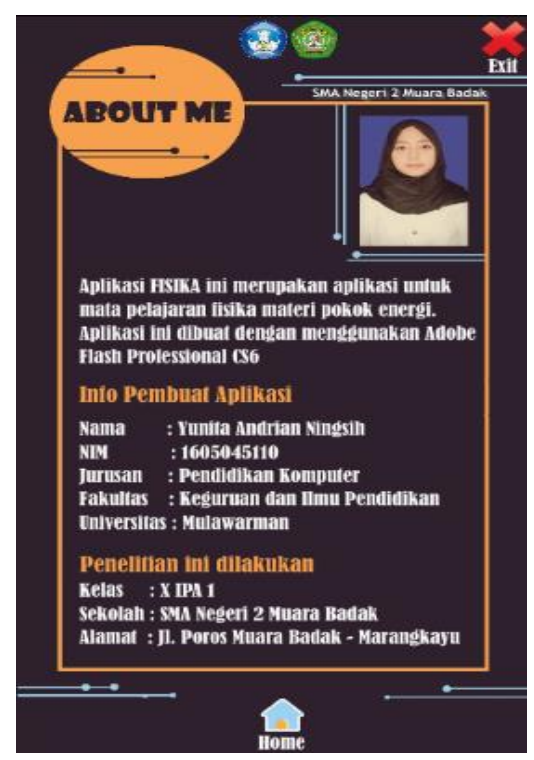

Gambar 14. Halaman tentang

2) Validasi oleh para ahli

a) Validasi ahli materi

Validasi yang dilakukan oleh ahli materi yaitu dengan mengumpulkan saran atau pendapat dari ahli materi untuk melakukan revisi. Angket menggunakan skala likert dengan 5 alternatif jawaban yaitu Sangat Setuju, Setuju, Cukup Setuju, Tidak Setuju dan Sangat Tidak Setuju. Angket untuk ahli materi memiliki 20 indikator penilaian yang dikelompokkan menjadi 5 aspek penilaian, untuk hasil rata-rata validasi ahli materi adalah sebagai berikut:

Tabel 4. Hasil Validasi Ahli Materi

\begin{tabular}{|c|c|c|c|c|}
\hline No & Aspek Penilaian & Jumlah Nilai & Rata-rata Nilai & Kategori \\
\hline \multicolumn{5}{|c|}{ Pembelajaran } \\
\hline 1. & Tujuan Pembelajaran & 22 & 22 & Sangat Layak \\
\hline 2. & Penyampaian Materi & 20 & 20 & Sangat Layak \\
\hline & Evaluasi & 19 & 19 & Sangat Layak \\
\hline \multicolumn{5}{|c|}{ Materi } \\
\hline 4. & Relevansi Materi & 15 & 15 & Sangat Layak \\
\hline 5. & Pemilihan Materi & 18 & 18 & Sangat Layak \\
\hline & Total & 94 & 94 & Sangat Layak \\
\hline
\end{tabular}

Berdasarkan hasil dari tabel 4, diperoleh skor rata-rata 94 yang masuk ke dalam rentang $\overline{\mathrm{X}} \leq 83,94$ dengan kategori sangat layak. Sehingga tingkat kelayakan media pembelajaran berdasarkan validasi ahli materi masuk ke dalam kategori Sangat Layak. Media dinyatakan layak untuk diujicobakan dengan revisi.

b) Validasi Ahli Media

Validasi media dilakukan oleh 3 orang Ahli media yaitu Bu Heliza Rahmania Hatta, S.Kom, M.Kom, Bapak Zainal Arifin, S.Kom., M.Kom, dan Bapak Putut Pamilih Widagdo, M.Kom. Validasi media dilakukan untuk mengkaji dan menilai apakah media yang dikembangkan sudah layak untuk 
diujicobakan. Validasi media dilakukan dengan mengisi angket yang menggunakan skala likert dengan 5 alternatif jawaban yaitu Sangat Setuju, Setuju, Cukup Setuju, Tidak Setuju dan Sangat Tidak Setuju. Angket untuk ahli media memiliki 25 indikator penilaian yang dikelompokkan menjadi 8 aspek penilaian, untuk hasil rata-rata validasi ahli media adalah sebagai berikut:

Tabel 5. Hasil Validasi Ahli Media

\begin{tabular}{|c|c|c|c|c|}
\hline No & Aspek Penilaian & Jumlah Nilai & Rata-rata Nilai & Kategori \\
\hline \multicolumn{5}{|c|}{ Tampilan Media Pembelajaran } \\
\hline 1. & Kualitas Pembuka & 40 & 13,3 & Sangat Layak \\
\hline 2. & Kualitas Teks & 52 & 17,3 & Layak \\
\hline 3. & Kualitas Background & 23 & 7,7 & Layak \\
\hline 4. & Kualitas Warna & 26 & 8,7 & Sangat Layak \\
\hline 5. & Kualitas Tombol & 58 & 19,3 & Layak \\
\hline 6. & Kualitas Gambar & 25 & 8,3 & Layak \\
\hline \multicolumn{5}{|c|}{ Penggunaan } \\
\hline 7. & Penggunaan & 25 & 8,3 & Layak \\
\hline 8. & Interaksi dengan Media & 48 & 16 & Layak \\
\hline & Total & 297 & 99 & Layak \\
\hline
\end{tabular}

Berdasarkan hasil dari tabel 5, diperoleh skor rata-rata 99 yang masuk ke dalam rentang 85,02 < $\overline{\mathrm{X}} \leq 105,06$ dengan kategori layak. Sehingga tingkat kelayakan media pembelajaran berdasarkan validasi ahli media masuk ke dalam kategori Layak. Media dinyatakan layak untuk diujicobakan dengan revisi.

c) Kesimpulan perhitungan ahli media dan ahli materi

Pada perhitungan ini merupakan kesimpulan dari hasil validasi ahli media dan ahli materi, untuk hasil rata-rata kesimpulan dari validasi ahli media dan ahli materi adalah sebagai berikut:

Tabel 6. Hasil Kesimpulan Validasi Ahli Media dan Ahli Materi

\begin{tabular}{cccc}
\hline Validator & Jumlah Nilai & Skor Rata-rata & Kategori \\
\hline Ahli Materi & 94 & 94 & Sangat Layak \\
Ahli Media & 297 & 99 & Layak \\
\hline Rata-rata & $\mathbf{1 9 5 , 5}$ & $\mathbf{9 6 , 5}$ & Sangat Layak \\
\hline
\end{tabular}

Berdasarkan hasil dari tabel 6, diperoleh skor rata-rata 96,5 yang masuk ke dalam rentang $\bar{X}>94,5$ dengan kategori sangat layak. Sehingga tingkat kelayakan media pembelajaran berdasarkan validasi ahli media dan ahli materi masuk ke dalam kategori Sangat Layak.

3) Uji coba pengembangan (developmental testing)

Pada tahap uji coba pengembangan, media pembelajaran yang telah divalidasi dan direvisi sesuai dengan saran dari ahli materi dan ahli media akan di uji cobakan ke siswa kelas X IPA 1 SMA Negeri 2 Muara Badak. Namun dikarenakan adanya Pandemi COVID-19, uji coba hanya dilakukan oleh 5 siswa kelas X IPA 1 SMA Negeri 2 Muara Badak. Setelah siswa menggunakan media pembelajaran ini, siswa diminta untuk mengisi angket yang disediakan. Angket yang diberikan merupakan angket penilaian terhadap media pembelajaran.

Validasi media pembelajaran dilakukan dengan mengisi angket yang menggunakan skala likert dengan 5 alternatif jawaban yaitu sangat setuju, setuju, cukup setuju, tidak setuju, dan sangat tidak setuju. Angket untuk siswa memiliki 8 indikator penilaian yang dikelompokkan menjadi 4 aspek penilaian, untuk hasil rata-rata validasi ahli media adalah sebagai berikut. 
Tabel 7. Hasil Validasi Siswa

\begin{tabular}{|c|c|c|c|c|}
\hline No & Aspek Penilaian & Jumlah Nilai & Rata-rata Nilai & Kategori \\
\hline \multicolumn{5}{|c|}{ Materi Pembelajaran } \\
\hline 1. & Pembelajaran & 46 & 9,2 & Sangat Layak \\
\hline & Materi & 50 & 10 & Sangat Layak \\
\hline \multicolumn{5}{|c|}{ Tampilan dan Pengoperasian Media Pembelajaran } \\
\hline 3. & Tampilan Media Pembelajaran & 43 & 8,6 & Sangat Layak \\
\hline & Penggunaan & 46 & 9,2 & Sangat Layak \\
\hline & Total & 185 & 37 & Sangat Layak \\
\hline
\end{tabular}

Berdasarkan dari tabel 7 diperoleh bahwa ditinjau dari aspek pembelajaran diperoleh hasil penilaian dengan nilai rata-rata 9,2 yang termasuk dalam kategori sangat layak, sedangkan aspek materi diperoleh hasil penilaian dengan nilai rata-rata 10 yang termasuk dalam kategori sangat layak, aspek tampilan media pembelajaran diperoleh hasil penilaian dengan nilai rata-rata 8,6 yang termasuk dalam kategori sangat layak, sedangkan aspek penggunaan diperoleh hasil penilaian dengan nilai rata-rata 9,2 yang termasuk dalam kategori sangat layak. Hasil penilaian dari aspek pembelajaran, aspek materi, aspek tampilan media pembelajaran dan aspek penggunaan masuk dalam rentang nilai $\overline{\mathrm{X}} \leq 8,34$ dengan skor keseluruhan diperoleh rata-rata 37 sehingga tingkat kelayakan media pembelajaran "Fisika" termasuk dalam kategori Sangat Layak.

\section{d. Tahap Penyebaran (Dissemination)}

Tahap penyebaran merupakan suatu tahap akhir penelitian pengembangan ini. Tahap ini bertujuan agar produk media pembelajaran dapat digunakan oleh semua siswa kelas X IPA 1 SMA Negeri 2 Muara Badak. Namun untuk saat ini dikarenakan keadaan di Indonesia sedang mengalami wabah virus COVID-19 sehingga dalam penelitian ini hanya digunakan penyebaran terbatas, yakni menyebarluaskan media pembelajaran berbasis android menggunakan Adobe Flash Professional CS6 hanya kepada ahli media, ahli materi, dan beberapa siswa saja.

Untuk penyebaran secara luas, media ini di sebarkan melalui website agar semua siswa kelas X IPA 1 SMA Negeri 2 Muara Badak bisa mengakses media pembelajaran dengan mudah. Media pembelajaran yang disebar berupa file apk.

\section{Kesimpulan}

Media pembelajaran ini dikembangkan dengan jenis penelitian $R \& D$ menggunakan model pengembangan 4D Thiagarajan. Tahap pendefinisian (define) melakukan analisis awal - akhir, analisis konsep, analisis tugas, dan analisis tujuan pembelajaran. Tahap perancangan (design) melakukan pembuatan tes intrumen dan pembuatan desain awal. Pada desain awal dilakukan pembuatan activity diagram, flowchart, storyboard, dan pembuatan bahan pendukung. Tahap pengembangan (development) melakukan uji kelayakan dengan validator. Tahap penyebaran (disseminate) melakukan penyebaran media pembelajaran secara terbatas.

Berdasarkan hasil rata-rata pengembangan media pembelajaran berbasis android dari ahli materi diperoleh rata-rata sebesar 94 dari skor maksimum 100 sehingga termasuk dalam kategori sangat layak dengan rentang $\bar{X}>83,94$. Selanjutnya penilaian oleh 3 ahli media diperoleh rata-rata sebesar 99 dari skor maksimum 125 sehingga termasuk dalam kategori layak dengan 85,02 $<\overline{\mathrm{X}} \leq 105,06$. Maka secara keseluruhan penilaian dari ahli materi dan ahli media terhadap pengembangan media pembelajaran berbasis android diperoleh rata-rata sebesar 96,5 dari skor maksimum 112,5 sehingga termasuk dalam kategori sangat layak digunakan sebagai media pembelajaran tambahan dalam belajar dengan rentang $\overline{\mathrm{X}}>94,5$. 


\section{Daftar Pustaka}

Arief S. S, dkk. (2003). Media Pendidikan, Pengertian, Pengembangan dan Pemanfaatan. PT. Raja Grafindo Persada. Jakarta.

Asyhari, A. dan Silvia, H. (2016). Pengembangan Media Pembelajaran Berupa Buletin Dalam Bentuk Buku Saku untuk Pembelajaran IPA Terpadu. Jurnal Ilmiah Pendidikan.

Arsyad, A. (2014). Media Pembelajaran. Rajawali Pers. Jakarta.

Daryanto. (2013). Media Pembelajaran: Perannya Sangat Penting Dalam Mencapai Tujuan Pembelajaran. Gava Media. Yogyakarta.

Delkisyarangga, B. (2017). Pengembangan Media Pembelajaran Berbasis Android Pada Kompetensi Dasar Mengidentifikasi Komponen Elektronika Daya (ELDA) Di SMK. Skripsi UNY. Yogyakarta.

Fitriyani, L. (2017). Pengembangan Media Pembelajaran Vlog (Video Blogging ) Pada Materi Usaha dan Energi Untuk Menumbuhkan Kemandirian dan Meningkatkan Penguasaan Konsep Fisika Siswa Kelas X SMAN 2 Ngaglik. Skripsi UNY. Yogyakarta.

Mubarok, F. (2015). Pengembangan Media Pembelajaran Berbasis Mobile Application Menggunakan App Inventor Pada Mata Pelajaran Matematika Teknik untuk Siswa Kelas X Studi Keahlian TGB SMK Negeri 3 Yogyakarta. Skripsi UNY. Yogyakarta.

Multyaningsih, E. (2011). Riset Terapan Bidang Pendidikan dan Teknik. UNY Pers. Yogyakarta

Oktiana, G. D. (2015). Pengembangan Media Pembelajaran Berbasis Android Dalam Bentuk Buku Saku Digital Untuk Mata Pelajaran Akuntansi Kompetensi Dasar Membuat Ikhtisar Siklus Akuntansi Perusahaan Jasa Di Kelas XI MAN 1 Yogyakarta Tahun Ajaran 2014/2015. Skripsi UNY. Yogyakarta.

Pramuaji, A. (2017). Pengembangan Media Pembelajaran Interaktif Pada Materi Pengenalan CorelDraw Sebagai Sarana Pembelajaran Desain Grafis Di SMK Muhammadiyah 2 Klaten Utara. Skripsi UNY. Yogyakarta.

Purwoko, S. A. (2019). Urutan Versi Android dari Awal Hingga Android $\quad Q \quad$ Terbaru 2019. Internet. Diakses pada tanggal 20 Januari 2020 dari https://jalantikus.com/tips/urutan-versiandroid/

Rayandra, A. (2012). Kreatif Mengembangkan Media Pembelajaran. Referensi. Jakarta.

Recruitment. (2019). Perkembangan Android Sistem dari Astro Hingga Pie. Internet. Diakses pada tanggal 20 Januari 2020 dari https://toghr.com/perkembangan-android-sistem

Safaat, N. (2015). Aplikasi Berbasis Android, Berbagai Implementasi dan Pengembangan Aplikasi Mobile Berbasis Android. Informatika. Bandung

Sugiyono. (2011). Metode Penelitian Pendidikan (Pendekatan Kuantitatif, Kualitatif, dan R\&D). Alfabeta. Bandung.

Sugiyono. (2015). Metode Penelitian \& Pengembangan (Research and Development/R\&D). Alfabeta. Bandung.

Sobry, S. (2013). Belajar dan Pembelajaran: Upaya Kreatif dalam Memwujudkan Pembelajaran yang Berhasil. Holistica. Lombok.

Suyono dan Hariyanto. (2011). Belajar dan Pembelajaran: Teori dan Konsep Dasar. Remaja Rosdakarya. Bandung.

Tegeh, M. I., Jampel, N. I., dan Pudjawan, K. (2014). Model Penelitian Pengembangan. Graha Ilmu. Yogyakarta

Unaisa. (2018). Pengembangan Media Pembelajaran Berbasis Adobe Flash Materi Prinsip Desain Di SMK Negeri 1 Saptosari. Skripsi UNY. Yogyakarta. 